\title{
Follicular fluid modulation of functional LH receptor induction in pig granulosa cells
}

\author{
K. G. Osteen†, L. D. Anderson*, L. E. Reichert, Jr $\ddagger$ and \\ Cornelia P. Channing \\ Departments of Physiology and *Anatomy, University of Maryland at Baltimore, School of \\ Medicine, $655 W$. Baltimore Street, Baltimore, Maryland 21201, and $\$$ Department of Biochemistry, \\ Albany Medical College, Albany, New York 12208, U.S.A.
}

\begin{abstract}
Summary. Follicular fluid was collected from small (1-2 mm), medium (3-5 mm) and large $(6-12 \mathrm{~mm})$ follicles of pigs, treated with charcoal to remove steroids, and tested for effects on the induction of functional $\mathrm{LH} / \mathrm{hCG}$ receptors in cultures of granulosa cells from small antral pig follicles. Granulosa cells were cultured for 2, 4 or 6 days in Medium $199+10 \%$ pig serum. Granulosa cells cultured in the presence of purified human FSH $(0 \cdot 1 \mu \mathrm{g} / \mathrm{ml}$, LER $8 / 117)$, insulin $(1 \mathrm{mU} / \mathrm{ml})$, cortisol $(0.01 \mu \mathrm{g} / \mathrm{ml})$ and thyroxine $\left(10^{-7} \mathrm{M}\right)$ accumulated a 4- to 8-fold increase in $\mathrm{LH} / \mathrm{hCG}$ receptors compared to control cultures. The amounts of cyclic AMP and progesterone secreted after exposure to ovine $\mathrm{LH}(1 \mu \mathrm{g} / \mathrm{ml}$ : NIH-S19) were also increased 2-3-fold and 80-100fold, respectively. Exposure to FSH alone resulted in lower amounts of $\mathrm{LH} / \mathrm{hCG}$ receptors with a concomitant decrease in optimum $\mathbf{L H}$ responses.

Addition of $12 \cdot 5-50 \%$ follicular fluid obtained from small (1-2 mm) follicles led to a dose-dependent inhibition of the FSH plus insulin, cortisol and thyroxine induction of LH/hCG receptors after 4 days of culture. Fluid from medium follicles showed reduced ability to inhibit $\mathrm{LH} / \mathrm{hCG}$ receptor induction, and fluid from large follicles exerted only a slight inhibition or no inhibition of receptor induction. Fluid from medium-sized and large follicles exerted a progressive dose-dependent stimulation of progesterone secretion by the granulosa cell cultures. The inhibitory activity was precipitated primarily with $70 \%$ ethanol and to a lesser degree by 36 and $90 \%$ ethanol. These studies demonstrate that induction of functional $\mathrm{LH} / \mathrm{hCG}$ receptors in cultures of pig granulosa cells from immature follicles is enhanced by including insulin, cortisol and thyroxine, in addition to $\mathrm{FSH}$, in the culture medium, and that follicular fluid modulates both receptor induction and progesterone secretion as a function of follicular maturation.
\end{abstract}

\section{Introduction}

The mechanisms whereby certain follicles are chosen to mature, ovulate and luteinize are poorly understood. Granulosa cells from large, preovulatory pig follicles have 10-50-fold more luteinizing hormone/human chorionic gonadotrophin $(\mathrm{LH} / \mathrm{hCG})$ receptors than do cells from small follicles (Channing \& Kammerman, 1973; Nakano, Akahori, Katayama \& Tojo, 1977). Concomitant with an increase in receptors for $\mathrm{LH}$, granulosa cells gradually develop the ability to secrete large amounts of progesterone and accumulate cyclic AMP in response to $\mathrm{LH}$ as follicular maturation progresses (Channing, 1970; Lindsey \& Channing, 1979; May \& Schomberg, 1984). Pig granulosa

$\dagger$ Present address: Department of Obstetrics and Gynecology, Division of Reproductive Endocrinology, Vanderbilt University, Nashville, Tennessee 37232, U.S.A. 
cells only express their full potential to secrete progesterone in vitro if they are exposed to the preovulatory LH surge in vivo (Channing, Brinkley \& Young, 1980). Monkey granulosa cells will also secrete increasing amounts of progesterone in vitro as the follicles mature and therefore the primate follicle must also respond to the preovulatory $\mathrm{LH} / \mathrm{FSH}$ surge in vivo to attain full capacity to secrete progesterone in culture (Channing, 1980).

Channing, Tsai \& Sachs (1976) observed that granulosa cells obtained from small pig follicles, when exposed in vitro to LH, follicle-stimulating hormone (FSH), insulin (I), cortisol (F) and thyroxine (T), could maximally secrete progesterone compared to cells incubated in $\mathrm{LH}+\mathrm{FSH}$ alone. May \& Schomberg $(1981,1984)$ observed that addition of FSH plus insulin to pig granulosa cells in culture could stimulate $\mathrm{LH} / \mathrm{hCG}$ receptor induction and progesterone secretion. However, components contained within pig follicular fluid also seem to influence granulosa cell maturation. Ledwitz-Rigby \& Rigby (1979) observed that follicular fluid obtained from small follicles inhibited basal and LH-stimulated progesterone secretion, whereas follicular fluid from large follicles enhanced granulosa cell progesterone secretion. Ledwitz-Rigby, Rigby, Long, Stewart \& McLean (1981) also reported that follicular fluid obtained from large follicles enhanced granulosa cell conversion of androgen to oestrogen. The present studies were designed to examine whether nonsteroidal intrafollicular components modulate the induction of functional $\mathrm{LH} / \mathrm{hCG}$ receptors and progesterone secretion in cultures of granulosa cells from immature pig follicles. Additionally, the induction of functional $\mathrm{LH} / \mathrm{hCG}$ receptors with $\mathrm{FSH}$, insulin, cortisol and thyroxine was validated as a bioassay for factors affecting granulosa cell maturation in vitro. The effects of Amicon PM-10 membrane filtration and ethanol precipitation upon these activities of pig follicular fluid were also examined to develop a standard preparation for analysis of further purification procedures.

\section{Materials and Methods}

Granulosa cell preparation and culture procedures. Ovaries were collected from sows at a local slaughterhouse in $0.9 \%(\mathrm{w} / \mathrm{v}) \mathrm{NaCl}$ plus $100 \mathrm{i}$.u. penicillin $/ \mathrm{ml}+100 \mu \mathrm{g}$ streptomycin $/ \mathrm{ml}$ in groups of 200-1000 and transported to the laboratory at room temperature. Within 3-5 h of ovary collection, granulosa cells were aspirated under aseptic conditions using a 20-gauge needle and 3-ml syringe from small (1-2 mm) follicles and separated from follicular fluid by centrifugation at $500 \mathrm{~g}$ (Channing \& Ledwitz-Rigby, 1975). The cells were washed three times in TC medium $199+5 \%$ pig serum (Gibco, Grand Island, NY). Cells were separated from wash medium by an additional centrifugation at $500 \mathrm{~g}$. The final washed granulosa cells were counted in a haemocytometer containing $0.06 \%$ trypan blue. Live cells (which excluded the dye) were then adjusted to a final concentration of 300000 cells/culture for 2- and 4-day incubations or 150000 cells/culture for 6-day incubations in Medium 199 containing 10\% pig serum, $1 \mathrm{~mm}$-glutamine (Gibco) and $50 \mu \mathrm{g}$ gentamicin sulphate/ml (Schering Corp., Kenilworth, NJ) added immediately before use. The cells were cultured for 2,4 or 6 days in $0.5 \mathrm{ml}$ of the above culture medium containing no additions, purified human FSH (LER 8/117;0.1 $\mu \mathrm{g} / \mathrm{ml})$, FSH with IFT ( $1 \mathrm{mU}$ porcine insulin/ml: Lilly, Indianapolis, IN; $0.01 \mu \mathrm{g} \mathrm{cortisol/ml;} 10^{-7} \mathrm{M}$-thyroxine, Sigma, St Louis, MO), or IFT alone. The purified human FSH $(895 \mathrm{U} / \mathrm{mg})$ had been treated with $\alpha$-chymotrypsin to inactivate the LH contaminant (Reichert, 1967) which was $5.7 \mathrm{i} . \mathrm{u} . / \mathrm{mg}$. After 2 and 4 days of incubation in Falcon Multiwell plates (No. 3008; Oxnarel, CA) at $37^{\circ} \mathrm{C}$ with $95 \%$ air and $5 \% \mathrm{CO}_{2}$, some cells were removed from culture for subsequent analysis of binding of ${ }^{125} \mathrm{I}$-labelled hCG. Other cells were additionally exposed to ovine $\mathrm{LH}(\mathrm{NIH}-\mathrm{S} 19,1 \mu \mathrm{g} / \mathrm{ml})$ for $1 \mathrm{~h}$ before removal from culture and measurement of intracellular cyclic AMP accumulation. Some cultures were continued for 2 additional days in the presence of $\mathrm{LH}$ alone (same concentration as above) to determine the responsiveness of the granulosa cells in culture to $\mathrm{LH}$ in terms of progesterone secretion. Cultures containing follicular fluid $(12.5 \%, 25 \%$ or $50 \%)$ were cultured for 4 days in the presence of FSH + IFT. Cells were assayed for DNA content using the method of Brunk, Jones \& James (1979). 
Progesterone. Progesterone concentrations in the media were determined by radioimmunoassay using an antiserum generated in sheep against an 11-hydroxyprogesterone-bovine serum albumin conjugate supplied by Dr Gordon Niswender. Culture medium was appropriately diluted and assayed without prior extraction with petroleum ether as described by Channing et al. (1976). The cross-reaction to $20 \alpha$-dihydroprogesterone was $<5 \%$ compared to progesterone (Channing \& Coudert, 1976).

LH/hCG binding. $\mathrm{LH}$ receptors on granulosa cells were measured utilizing ${ }^{125}$ I-labelled hCG since LH and hCG are thought to share the same binding sites on ovarian cells. Addition of unlabelled LH and hCG can inhibit binding of ${ }^{125}$ I-labelled hCG to granulosa cells (Sakai, Channing \& Engel, 1977). Highly purified hCG obtained from Dr Robert Canfield (CR 117; 14000 i.u./mg) was iodinated with $1 \mathrm{mCi}^{125}$ I (New England Nuclear, Boston, MA) in aliquants of $10 \mu \mathrm{g}$, utilizing the chloramine-T technique originally described by Greenwood, Hunter and Glover (1963) and modified by Sakai et al. (1977). The hormone $(10 \mu \mathrm{g})$ plus ${ }^{125}$ I was mixed with an equal amount of chloramine-T and then iodinated at $4^{\circ} \mathrm{C}$ for $30 \mathrm{sec}$. The hCG was iodinated to a specific activity of $25-50 \mu \mathrm{Ci} / \mu \mathrm{g}$. Counting of ${ }^{125} \mathrm{I}$ was $67 \%$ efficient. Binding studies were carried out in siliconized $12 \times 75 \mathrm{~mm}$ glass test tubes according to the methodology described by Sakai et al. (1977). Briefly, about 200000 granulosa cells were incubated in the presence of $5 \mathrm{ng}{ }^{125} \mathrm{I}$-labelled hCG with or without an additional $10 \mu \mathrm{g}$ ovine LH (NIH-S19) for determination of non-specific binding. All incubations were carried out for $1 \mathrm{~h}$ at $37^{\circ} \mathrm{C}$.

cAMP accumulation. The accumulation of intracellular cAMP was measured utilizing a radioimmunoassay kit for cAMP determination purchased from New England Nuclear, Boston, MA. The sensitivity of the assay was 0.1 pmol cAMP per tube.

Follicular fluid collection and treatment. Follicular fluid was collected from small (1-2 mm), medium sized (3-5 mm) and large $(6-12 \mathrm{~mm})$ follicles by aspiration at $4^{\circ} \mathrm{C}$. An attempt was made to avoid aspiration of grossly atretic, cloudy, follicles. All fluids were centrifuged for $20 \mathrm{~min}$ at $1000 \mathrm{~g}$ to remove cell debris and frozen at $-35^{\circ} \mathrm{C}$ until use. Four pools of whole follicular fluid were made consisting of 5-10 days of collections. Immediately before freezing, the follicular fluid was treated with 2 mM-phenylmethylsulphonylfluoride (PMSF) for $30 \mathrm{~min}$ to inactivate available serine proteases. The PMSF was made as a 100 -fold solution in absolute ethanol and added dropwise to the follicular fluid so that one part of the PMSF solution was added to 100 parts of follicular fluid.

Oocytes recovered from these pools were examined under the binocular microscope and evaluated for gross signs of atresia: $<20-30 \%$ of the oocytes were denuded of granulosa cells (evidence of atresia). The other oocytes had healthy looking cumuli which were intact (in most instances) or partly removed. Therefore, $<30 \%$ of the follicles that yielded these oocytes and fluid were grossly atretic. Oocytes recovered from follicles that had intact cumuli were cultured for 42-44 $\mathrm{h}$ in groups of $40-50$ and had a $50-70 \%$ nuclear maturation rate (see Stone, Pomerantz, Kripner \& Channing, 1978). Atresia was similar to that reported by Ryan (1981) and far less in some instances. Follicular fluid in the non-sterile state was only allowed to stand for $2-3 \mathrm{~h}$ at $4^{\circ} \mathrm{C}$ or room temperature since Sluss \& Reichert (1983) have observed that raw non-sterile porcine follicular fluid allowed to stand at $4^{\circ} \mathrm{C}$ for 1-2 days develops bacterial growth which can generate an FSHbinding inhibitor. Our collection procedure, which involved placing the ovaries in sterile $0.9 \%$ $\mathrm{NaCl}$ plus penicillin and streptomycin, served to wash away bacteria which might be associated with the ovaries collected at the slaughterhouse. The follicular fluid was sterilized by filtration $(0 \cdot 22$ $\mu \mathrm{g}$; Millipore-Millex HA, Bedford, MA) and the progesterone concentration of each pool was measured as detailed by Channing \& Coudert (1976). Before the final $0.22 \mu \mathrm{m}$ filtration the fluid was prefiltered through filters of $1 \cdot 2,0.8$ and $0.45 \mu \mathrm{m}$. In all procedures the follicular fluid was kept under reasonably aseptic conditions and not allowed to stand. When untreated follicular fluid was added to granulosa cell cultures the progesterone content of the added follicular fluid was subtracted from subsequent progesterone secretion data. In additional experiments follicular fluid recovered from small $(1-3 \mathrm{~mm})$, medium-sized (3-5 mm) and large (6-12 mm) pig follicles were 
treated with charcoal to remove steroids before addition to granulosa cell cultures. The follicular fluid pool $(200 \mathrm{ml})$ was mixed with $10 \%$ (v/v) activated charcoal (Norite A, Fisher Pittsburgh, PA) and the mixture stirred overnight at $4{ }^{\circ} \mathrm{C}$. The following day, the mixture was centrifuged at $3000 \mathrm{~g}$ for $30 \mathrm{~min}$, followed by centrifugation at $100000 \mathrm{~g}$ for $60 \mathrm{~min}$. The fluid was then serially filtered through a prefilter, and filters of $1.2,0.8,0.45$ and $0.22 \mu \mathrm{m}$ to remove charcoal and to render the fluid sterile. Charcoal treatment in this manner reduced the oestrogen and progesterone content of the fluid to non-detectable levels as determined by radioimmunoassay $(<0.1 \mathrm{ng} / \mathrm{ml}$ for both). After charcoal treatment, the follicular fluid was extracted with diethyl ether or petroleum ether for oestrogen and progesterone determinations, respectively.

The charcoal-treated follicular fluid was further separated into the high and low molecular weight fractions by filtration on an Amicon PM-10 membrane. Each charcoal-treated follicular fluid pool was added in a $100 \mathrm{ml}$ sample to a PM-10 membrane and the Amicon cell stirred overnight at $4^{\circ} \mathrm{C}$ under $0.7-1.4 \mathrm{~kg} \mathrm{~N} / \mathrm{cm}^{2}$. The filtrate was recovered and added to culture without further treatment after sterile filtration through a $0.22 \mu \mathrm{m}$ filter. The retentate was recovered from the cell and reconstituted to half the original volume of the starting fluid with distilled water. Subsequently it was reconstituted to the original volume of follicular fluid with culture medium and filtered through a $0.22 \mu \mathrm{m}$ filter preceded by filtration through filters of $1.2,0.8$ and $0.45 \mu \mathrm{m}$. Filtrate, retentate and follicular fluid were added at a dose of $50 \%$ the final culture volume.

Follicular fluid recovered from small follicles was also treated with various concentrations of ethanol to determine which concentration precipitated the bulk of luteinization inhibitory activity. Samples $(50 \mathrm{ml})$ of fluid recovered from 1-2 $\mathrm{mm}$ follicles were mixed with cold absolute ethanol such that the final concentration of ethanol was $20,30,50,70$ or $90 \%: 100 \mathrm{ml}$ fluid were brought to 5,10 and $15 \%$. The mixture was allowed to stand overnight at $4{ }^{\circ} \mathrm{C}$ followed by centrifugation and freeze-drying of the precipitate to dryness. This precipitate was added to granulosa cell cultures at 1 or $10 \mathrm{mg} / \mathrm{ml}$.

Statistical analysis of data. Data were subjected to Analysis of Variance and Duncan's New multiple range test. Cochran's test for heterogeneity was applied and if the data were heterogeneous the data were transformed to the logarithm before analysis. A $P$ value of $<0.05$ was considered significant. Each experiment was repeated on 2-6 separate collections of granulosa cells to confirm reproducibility.

\section{Results}

\section{Binding of $h C G$}

As shown in Text-fig. 1 the amount of ${ }^{125}$ I-labelled hCG specifically bound to granulosa cells from small follicles increased 4-5-fold above Day 0 values by Day 2 when the cells were cultured in the presence of FSH or FSH + IFT $(P<0 \cdot 01)$. Addition of IFT alone did not bring about a significant increase in hCG binding. After 4 days of culture, FSH + IFT brought about an 8-fold increase in hCG binding $(P<0.05)$ compared with control value.

Preliminary observations demonstrated that addition of 0.1 or $1.0 \mu \mathrm{g}$ FSH both resulted in similar increases in hCG binding (M. Loeken \& C. P. Channing, unpublished data). In most experiments the specific binding was $80-90 \%$ of total binding.

\section{Cyclic AMP accumulation}

As shown in Text-fig. 2, after 2 days of culture with FSH or FSH + IFT, granulosa cells accumulated significantly more intracellular cyclic AMP than did Day 0 cells when exposed to LH for $1 \mathrm{~h}(P<0 \cdot 05)$. The LH response of cells incubated in control or IFT media for 2 days did not significantly change from Day 0 values. The amount of cyclic AMP accumulated in response to LH did not differ between FSH and FSH + IFT at Day 2, but was highest in FSH + IFT containing cultures on Day $4(P<0.05)$. 


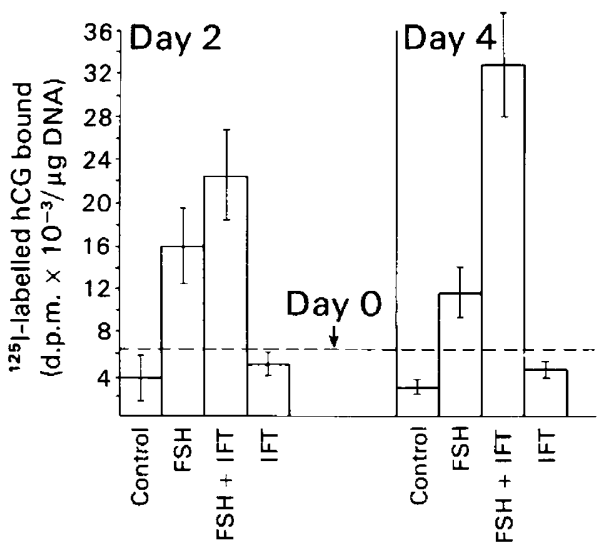

Text-fig. 1. Effect of insulin, cortisol and thyroxine (IFT) and FSH + IFT upon induction of ability of pig granulosa cells to bind iodinated hCG. Granulosa cells from small antral follicles were cultured for 0, 2 or 4 days in Medium 199 and $10 \%$ pig serum containing no exogenous hormones (control), hFSH (LER $8 / 117 ; 0.1 \mu \mathrm{g} / \mathrm{ml}), \mathrm{hFSH}$ with IFT ( $1 \mathrm{mU}$ insulin $/ \mathrm{ml}, 0.01 \mu \mathrm{g}$ cortisol $/ \mathrm{ml}, 10^{-7} \mathrm{M}$-thyroxine) or IFT alone. At the end of each incubation the cells were removed from the wells by scraping with a rubber policeman into saline $(9 \mathrm{~g} \mathrm{NaCl} / 1)$. Aliquants of the cells were taken for determination of ${ }^{125} \mathrm{I}$-labelled $\mathrm{hCG}$ binding and for DNA content. The values represent the mean \pm s.e.m. $(n=8)$ of 4 separate experiments. Day 0 values are those of ${ }^{125} \mathrm{I}$-labelled hCG bound to the cells on the day of collection.

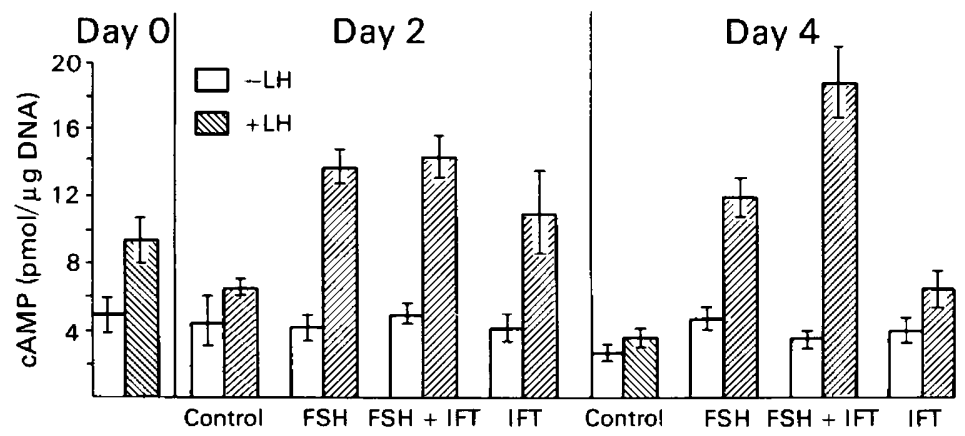

Text-fig. 2. Effect of FSH, insulin, cortisol and thyroxine (IFT) and FSH + IFT upon the ability of pig granulosa cells to respond to LH by accumulation of cyclic AMP. Granulosa cells from small antral follicles were cultured for 0, 2 or 4 days in Medium 199 and $10 \%$ pig serum containing no exogenous hormones (control), hFSH (LER 8/117;0.1 $\mu \mathrm{g} / \mathrm{ml}$ ), hFSH with IFT ( $1 \mathrm{mU}$ insulin $/ \mathrm{ml}, 0.01 \mu \mathrm{g}$ cortisol $/ \mathrm{ml}, 10^{-7}$ M-thyroxine) or IFT alone. At the end of each incubation the cells were removed from the wells by scraping with a rubber policeman into saline $(9 \mathrm{~g} \mathrm{NaCl} / \mathrm{l})$. Aliquants of the cells were taken and incubated for an additional $1 \mathrm{~h}$ in the absence or presence of ovine $\mathrm{LH}(\mathrm{NIH}-\mathrm{S} 19,1 \mu \mathrm{g} / \mathrm{ml}$ ) for determination of intracellular cyclic AMP. Separate aliquants were taken for DNA determination. The values represent the mean \pm s.e.m. $(n=4)$.

\section{Progesterone secretion}

As shown in Text-fig. 3, granulosa cells from small follicles secreted significantly more progesterone than control cultures when cultured in FSH or FSH + IFT $(P<0 \cdot 01)$. FSH + IFTcontaining cultures secreted greater than 100-fold more progesterone than the control cells. Cultures grown for 4 days exhibited similar increases in progesterone secretion over control levels when grown with both FSH and FSH + IFT. Progesterone secretion was significantly greater in cultures containing FSH + IFT than in cultures containing FSH alone at both culture periods 


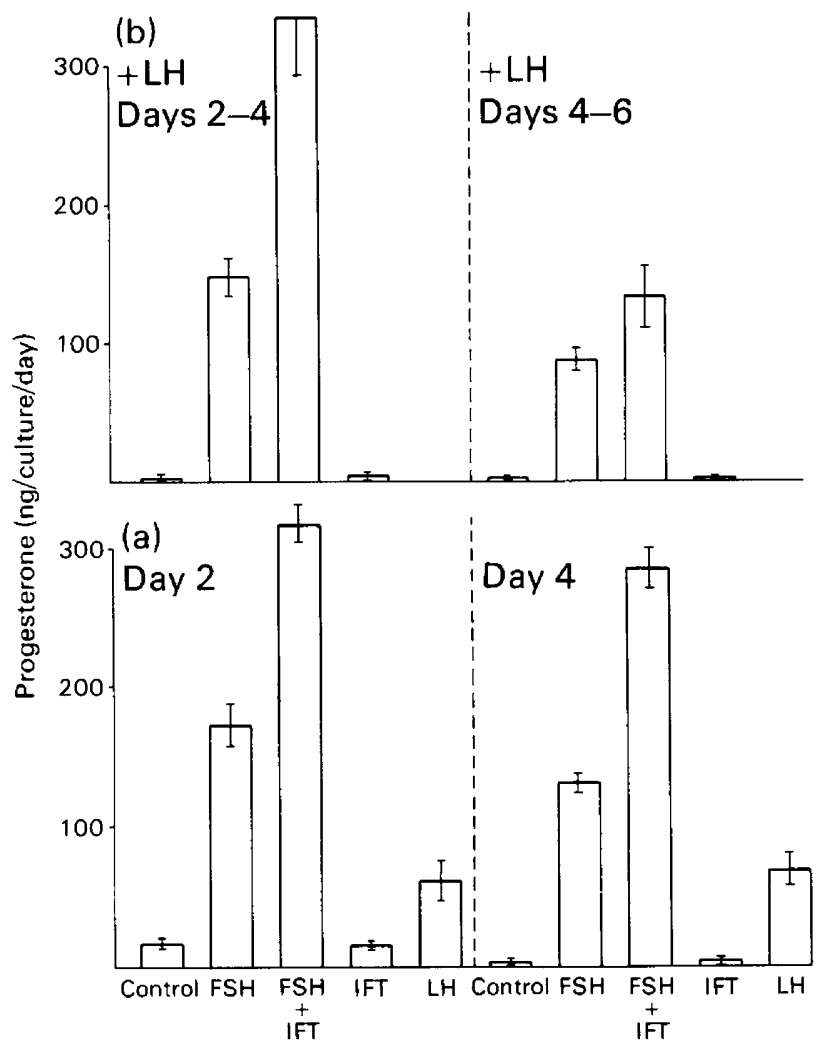

Text-fig. 3. Effect of FSH, insulin, cortisol and thyroxine (IFT) and FSH + IFT upon the ability of cultured pig granulosa cells to (a) secrete progesterone and (b) respond to LH with increased progesterone secretion. Granulosa cells from small antral follicles were cultured for 2 or 4 days in Medium 199 and $10 \%$ pig serum containing no exogenous hormones (control), hFSH (LER $8 / 117 ; 0.1 \mu \mathrm{g} / \mathrm{ml})$, hFSH + IFT ( $1 \mathrm{mU}$ insulin $/ \mathrm{ml}, 0.01 \mu \mathrm{g}$ cortisol $/ \mathrm{ml}, 10^{-7} \mathrm{M}$ thyroxine), IFT alone or LH (NIH-S19, $1 \mu \mathrm{g} / \mathrm{ml})$. In (b) ovine $\mathrm{LH}(\mathrm{NIH}-\mathrm{S} 19,1 \mu \mathrm{g} / \mathrm{ml})$ was added to the cultures for an additional 2 days. The spent medium was then removed and the content of progesterone determined by specific radioimmunoassay. The values represent the mean \pm s.e.m. for 4 experiments (a) or 2 experiments (b).

examined $(P<0.05)$. Additionally, cultures containing $\mathrm{LH}$ secreted significantly more progesterone than did control cultures $(P<0.05)$ while cultures containing IFT alone did not secrete more progesterone than control cultures. However LH alone was much less effective in inducing progesterone secretion than was FSH alone or FSH + IFT.

Additional granulosa cell cultures were preincubated for 2 or 4 days with the various FSH and IFT combinations before being incubated for 2 more days in the presence of LH alone (Text-fig. 3). Cells preincubated with FSH alone or FSH + IFT secreted significantly more progesterone during 2 days exposure to $\mathrm{LH}$ than did control cultures or cultures containing only IFT at both culture periods examined $(P<0.05)$. Progesterone secretion in cultures containing FSH + IFT was greater than in cultures containing FSH alone. Cultures treated with IFT alone (no FSH) did not respond to $\mathrm{LH}$ with progesterone secretion above control values at either time period examined.

\section{Follicular fluid effects}

Neat follicular fluid. The effects of neat follicular fluid from small (1-2 mm) and large (6-12 $\mathrm{mm})$ follicles on FSH + IFT-induced LH/hCG receptor generation and stimulation of progesterone 
secretion are shown in Table 1. Follicular fluid from small follicles significantly inhibited progesterone secretion in granulosa cell cultures below control values even at the most dilute $(12.5 \%)$ concentration $(P<0.01)$. However, a dose-dependent effect was indicated since at $12.5 \%$ the inhibition of progesterone secretion was significantly less than at $50 \%$ follicular fluid $(P<$ $0.05)$. Follicular fluid obtained from large follicles significantly stimulated ( $50 \%$ fluid) progesterone secretion $(P<0.05)$ or had no effect compared to control cultures $(25 \%$ and $12.5 \%$ fluid $)$. Cultures containing $50 \%$ fluid from large follicles also secreted significantly more progesterone $(P<0.05)$ than did cultures containing $12.5 \%$ fluid.

Table 1. The effect of neat follicular fluid from small or large pig follicles on progesterone secretion and $\mathrm{FSH}$-induced acquisition of $\mathrm{LH} / \mathrm{hCG}$ receptors by pig granulosa cells in vitro $\dagger$

\begin{tabular}{|c|c|c|c|}
\hline $\begin{array}{l}\text { Follicle } \\
\text { size }\end{array}$ & $\begin{array}{l}\text { Fluid } \\
\text { conc. }\end{array}$ & $\begin{array}{c}\text { Specific binding of } \\
125 \mathrm{I} \text {-labelled hCG } \\
(\% \text { of control) } \ddagger\end{array}$ & $\begin{array}{l}\text { Progesterone secretion } \\
\text { (ng/culture/day) }\end{array}$ \\
\hline Control & & 100 & $206.9 \pm 15.3$ \\
\hline Small & $\begin{array}{r}50 \% \\
25 \% \\
12.5 \%\end{array}$ & $\begin{array}{l}22 \cdot 6 \pm 2 \cdot 6^{* *} \\
30 \cdot 1 \pm 2 \cdot 9^{* *} \\
36 \cdot 2 \pm 2 \cdot 7^{* *}\end{array}$ & $\begin{array}{r}68.4 \pm 6.8^{*} \\
80.1 \pm 7.7^{*} \\
116.6 \pm 8.6^{*}\end{array}$ \\
\hline Large & $\begin{array}{r}50 \% \\
25 \% \\
12.5 \%\end{array}$ & $\begin{array}{l}61 \cdot 5 \pm 5 \cdot 2^{*} \\
67 \cdot 2 \pm 5 \cdot 9^{*} \\
75 \cdot 2 \pm 12 \cdot 7\end{array}$ & $\begin{array}{l}285.1 \pm 26.9^{*} \\
226.5 \pm 23.9 \\
176.7 \pm 24.4\end{array}$ \\
\hline
\end{tabular}

+ Granulosa cells from small antral follicles were cultured for 2 or 4 days in Medium 199 and $10 \%$ pig serum containing FSH (LER $8 / 117 ; 0.1 \mu \mathrm{g} / \mathrm{ml}$ ), insulin (1 $\mathrm{mU} / \mathrm{ml})$, cortisol $(0.01 \mu \mathrm{g} / \mathrm{ml})$ and thyroxine $\left(10^{-7} \mathrm{M}\right)$.

$\ddagger$ After 4 days of culture. Values represent the mean \pm s.e.m. for 3 determinations from 3 separate culture experiments.

$\S$ From Days 0 to 2 of culture. Values represent the mean \pm s.e.m. for 4 determinations from 3 separate experiments.

Compared with control value: ${ }^{*} P<0.05,{ }^{* *} P<0.01$.

Fluid from small or large follicles inhibited the induction of $\mathrm{LH} / \mathrm{hCG}$ receptors by FSH + IFT below the $95 \%$ confidence limits of cultures containing FSH + IFT alone. However, fluid from small follicles inhibited receptor induction significantly below the inhibition observed with the same dose of fluid from large follicles $(P<0.01)$. The most dilute dose of fluid from small follicles was significantly less effective in inhibiting $\mathrm{LH} / \mathrm{hCG}$ receptor induction when compared to the $50 \%$ dose $(P<0.05)$.

Charcoal-treated Amicon-filtered follicular fluid. Addition of charcoal-treated follicular fluid $(50 \%)$ recovered from follicles of all sizes and its high and low molecular weight fractions led to a significant depression $(P<0.05)$ in ${ }^{125} \mathrm{I}$-labelled hCG binding to the cells as compared to control cultures incubated with FSH + IFT alone (Table 2). However, both whole follicular fluid and the PM-10 retentate $\left(M_{\mathrm{r}}>10000\right)$ from small follicles inhibited $\mathrm{LH} / \mathrm{hCG}$ receptor induction significantly $(P<0.05)$ compared to the level observed with whole fluid or retentate from large follicles. The PM-10 filtrates $\left(M_{\mathrm{r}}<10000\right)$ of follicular fluid from small, medium or large follicles were similar in their effect on induction of $\mathrm{LH} / \mathrm{hCG}$ receptors. Nevertheless, the PM-10 filtrate could contain some toxic low molecular weight material and further studies are being undertaken. Whole follicular fluid from medium-sized follicles was not different from whole fluid from large follicles with regard to the induction of $\mathrm{LH} / \mathrm{hCG}$ receptors; however, the PM-10 retentate of fluid from large follicles permitted more receptor induction than did the PM-10 retentate from mediumsized follicles $(P<0.05)$. 
Table 2. Effect of $50 \%$ charcoal-treated follicular fluid fractions from small, medium or large pig follicles on progesterone secretion and FSH-induced acquisition of $\mathrm{LH} / \mathrm{hCG}$ receptors by pig granulosa cells over 4 days in vitro (see text)

\begin{tabular}{|c|c|c|}
\hline & 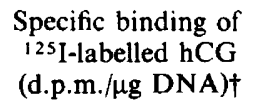 & 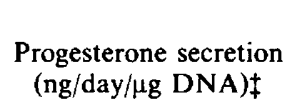 \\
\hline Control (no hormones added) & $300 \pm 25^{9}$ & $127 \pm 15^{f}$ \\
\hline FSH + IFT alone & $1620 \pm 57^{\mathrm{a}}$ & $365 \pm 37^{c}$ \\
\hline $\begin{array}{l}\text { Fluid from small follicles } \\
\text { Whole } \\
\text { Filtrate } \\
\text { Retentate }\end{array}$ & $\begin{array}{l}312 \pm 20^{9} \\
962 \pm 71^{\mathrm{d}} \\
487 \pm 28^{\mathrm{f}}\end{array}$ & $\begin{array}{l}277 \pm 35^{\mathrm{d}} \\
192 \pm 37^{\mathrm{e}} \\
299 \pm 39^{\mathrm{d}}\end{array}$ \\
\hline $\begin{array}{l}\text { Fluid from medium follicles } \\
\text { Whole } \\
\text { Filtrate } \\
\text { Retentate }\end{array}$ & $\begin{array}{r}725 \pm 29^{\mathrm{e}} \\
1050 \pm 72^{\mathrm{c}} \\
869 \pm 29^{\mathrm{d}}\end{array}$ & $\begin{array}{l}536 \pm 40^{\mathrm{a}, \mathrm{b}} \\
176 \pm 47^{\mathrm{e}, \mathrm{f}} \\
525 \pm 36^{\mathrm{a}, \mathrm{b}}\end{array}$ \\
\hline $\begin{array}{l}\text { Fluid from large follicles } \\
\text { Whole } \\
\text { Filtrate } \\
\text { Retenate }\end{array}$ & $\begin{aligned} 847 & \pm 39^{\mathrm{d}} \\
1018 & \pm 57^{\mathrm{c}} \\
1138 & \pm 50^{\mathrm{b}}\end{aligned}$ & $\begin{array}{l}478 \pm 50^{\mathrm{b}, \mathrm{c}} \\
172 \pm 32^{\mathrm{e}, \mathrm{f}} \\
692 \pm 79^{\mathrm{a}}\end{array}$ \\
\hline
\end{tabular}
$0 \cdot 05)$.

a-g $P<0.05$ compared with other values. Values having different letters $\operatorname{differ}(P<$

† On day of collection (Day 0 ) specific binding was $445 \pm 48$ d.p.m./ $\mu \mathrm{g}$ DNA. Values are mean \pm s.e.m. for 3 determinations from 3 separate cultures.

$\ddagger$ Values, from Days 2 to 4 of culture, are mean \pm s.e.m. for 6 determinations from 3 separate cultures.

Quantitatively, the PM-10 retentate had more inhibitory activity compared to filtrate and the inhibitory activity of the retentate changed with the size of follicles used as a source of fluid, i.e. there was more inhibitory activity in fluid recovered from small than from large follicles.

As was also shown in Text-fig. 1, addition of FSH + IFT alone significantly increased basal progesterone secretion in cultures of granulosa cells from the small follicles compared to control cultures between 2 and 4 days of culture (Table 2). Whole follicular fluid from small follicles significantly inhibited progesterone secretion in these cultures while the high molecular weight

Table 3. Ethanol precipitation of pig follicular fluid

\begin{tabular}{ccccc}
\hline $\begin{array}{c}\text { Volume } \\
\text { of fluid } \\
\text { applied }(\mathrm{ml})\end{array}$ & $\begin{array}{c}\% \\
\text { of ethanol } \\
\text { achieved }\end{array}$ & $\begin{array}{c}\text { Dry wt (mg) } \\
\text { precipitate }\end{array}$ & Supernatant & $\begin{array}{c}\text { Dry wt } \\
\text { precipitate } \\
\text { as \% or } \\
\text { total dry wt in } \\
\text { follicular fluid }\end{array}$ \\
\hline 100 & 5 & 290 & 7520 & $3 \cdot 6$ \\
100 & 10 & 400 & 6750 & $5 \cdot 0$ \\
100 & 15 & 410 & 6450 & $5 \cdot 1$ \\
50 & 20 & 980 & 3400 & $24 \cdot 5$ \\
50 & 36 & 2000 & 1780 & $50 \cdot 0$ \\
50 & 50 & 3010 & 418 & $75 \cdot 2$ \\
50 & 70 & 2720 & 402 & $68 \cdot 0$ \\
50 & 90 & 3380 & 359 & 84.5 \\
\hline
\end{tabular}

Dry weight of $50 \mathrm{ml}$ starting follicular fluid from small (1-2 mm) follicles was $4000 \mathrm{mg}$. Aliquants of each precipitate were assayed in 2 bioassays, the data of which are shown in Text-fig. 4. 


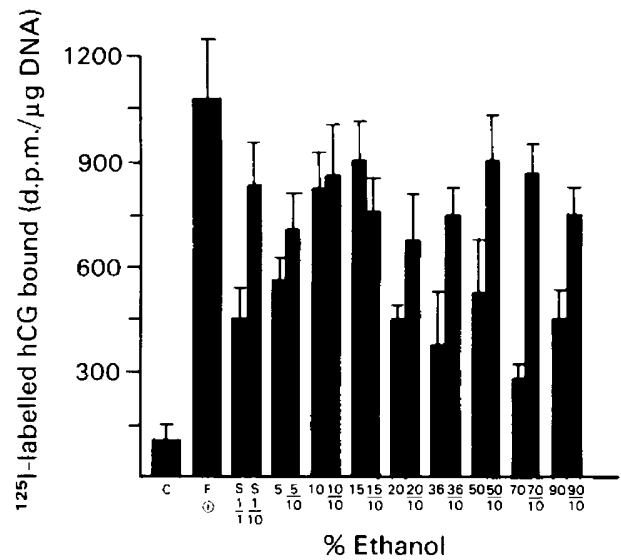

Text-fig. 4. Effect of ethanol precipitation of follicular fluid from small pig follicles upon inhibitory activity upon FSH induction of ${ }^{125} \mathrm{I}$-labelled hCG binding. Conditions of the experiment are described in the text: $1 / 10$ is equivalent to $1 \mathrm{mg} / \mathrm{ml}$ and $1 / 1$ is equivalent to 10 $\mathrm{mg} / \mathrm{ml}$ ethanol precipitate. All cultures contained FSH + IFT except the control (C). The zero hour binding was 268 d.p.m./ $\mu$ g cell DNA. S represents starting follicular fluid. F $\oplus$ refers to a control culture with FSH + IFT. Data are from 2 experiments and represent the mean \pm s.e.m. of 4 individual values.

fraction (PM-10 filtrate) from all follicular fluids tested significantly inhibited progesterone secretion below the level observed with FSH + IFT alone. However, both whole fluid and PM-10 retentate from medium or large follicles stimulated progesterone secretion significantly above the level of cultures containing FSH + IFT alone. The highest level of progesterone secretion was observed in cultures containing PM-10 retentate from large follicles.

level of cultures containing FSH + IFT alone. The highest level of progesterone secretion was observed in cultures containing PM-10 retentate from large follicles.

Ethanol precipitation of follicular fluid recovered from small follicles. As is evident from data presented in Text-fig. 4, inhibitory activity on FSH induction of hCG/LH binding sites precipitated primarily in $70 \%$ ethanol with activity precipitating to a lesser degree in 20,36 and $90 \%$ ethanol. Much of the dry weight from follicular fluid was precipitated by $70 \%$ ethanol (Table $3)$.

\section{Discussion}

The observations reported in the present study demonstrate that the addition of either FSH alone or a mixture of FSH + IFT can induce functional LH/hCG binding sites on pig granulosa cells, in vitro. Functional $\mathrm{LH} / \mathrm{hCG}$ binding sites were assessed by $\mathrm{LH}$ stimulation of intracellular cyclic AMP accumulation and progesterone secretion. The addition of FSH + IFT resulted in, not only a significant 8-fold increase in ${ }^{125} \mathrm{I}$-labelled hCG binding (Text-fig. 1), but a concomitant 2-3-fold increase in the ability of LH to stimulate cyclic AMP accumulation (Text-fig. 2) and up to an 80 100-fold increase in LH stimulation of progesterone secretion (Text-fig. 3). The synergism of IFT on FSH induction of $\mathrm{LH} / \mathrm{hCG}$ receptors was significant after 4 days of incubation. Preincubation of cells for 2 days with IFT maintained LH responsiveness in terms of cyclic AMP accumulation, but apparently this LH induced elevation in cyclic AMP was not transmitted to the steroidogenic response since there was no increase in progesterone secretion during a 2-4-day post-incubation with LH (Text-fig. 3). Both FSH and LH stimulated progesterone secretion during 0-2 and 2-4 days of culture, but the progesterone response was greatest if FSH was added (Text-fig. 3). The different responses to gonadotrophic stimulation may be due to the reported predominance of FSH receptors 
compared to LH receptors in granulosa cells from small pig follicles (Nakanon et al., 1977). To obtain greater responsiveness to LH in granulosa cells from small follicles, pretreatment with FSH is required to induce functional $\mathrm{LH} / \mathrm{hCG}$ receptors (compare Text-figs $3 \mathrm{a} \& 3 \mathrm{~b}$ ). We think the loss of $\mathrm{LH} / \mathrm{hCG}$ receptors in control cultures, those without FSH + IFT, is probably due to a lack of hormones which are required to maintain existing levels of receptors as well as induce new ones. It is also possible that changes in surface area during culture, i.e. having half the cell exposed to a surface, could block surface receptors for hCG.

Previous studies using pig granulosa cells to investigate induction of $\mathrm{LH} / \mathrm{hCG}$ receptors in monolayer culture with media containing $10 \%$ fetal calf serum revealed that insulin is required for the induction of functional $\mathrm{LH} / \mathrm{hCG}$ receptors (in terms of $\mathrm{hCG}$-stimulatable progesterone secretion) by FSH (May, McCarty, Reichert \& Schomberg, 1980; May \& Schomberg, 1981, 1984). In contrast, the present study demonstrates that FSH by itself can induce the appearance of new functional $\mathrm{LH} / \mathrm{hCG}$ receptor in the absence of other exogenous hormones (IFT) after 2 and 4 days of incubation in media containing $10 \%$ porcine serum. However, in the presence of IFT, FSH induction of functional $\mathrm{LH} / \mathrm{hCG}$ receptors was greatly enhanced. The difference between the present study and others employing the monolayer culture system may stem from dissimilarity in the type of serum used in the incubation media.

The concept that intragonadal factors contribute a significant role in reproductive processes is gaining acceptance and momentum. Follicular fluid from immature pig follicles has been shown to inhibit progesterone secretion in cultures of pig granulosa cells from large preovulatory follicles (Ledwitz-Rigby et al., 1977, 1981; Ledwitz-Rigby \& Rigby, 1979). "Luteinization inhibitors" have also been reported from bovine (Amsterdam, Riesel, Mintz, Shemesh \& Salomon, 1979; Shemesh, 1979; Bernard, 1973, 1975) and human (Hillensjö et al., 1978; Kraiem, Druker \& Lunenfield, 1978; Kumari, Vohra \& Rayhavan, 1983) follicular fluid. Follicular fluid from large pig follicles has also been shown to stimulate progesterone secretion in cultures of granulosa cells from immature follicles (Ledwitz-Rigby \& Rigby, 1979; Channing et al., 1982). The relation between the inhibitory protein isolated by DiZerega, Goebelsmann \& Nakamura (1982) from human follicular fluid and the luteinization inhibitor is not known since these authors used aromatase as an end point of inhibitory activity, and we used inhibition of progesterone secretion and FSH induction of $\mathrm{LH} / \mathrm{hCG}$ receptor as end points of action. Nevertheless, the protein isolated is of interest since it has been partly purified by gel-exclusion HPLC and orange A gel-adsorption chromatography and has a molecular weight between 14000 and 18000 . The present study confirms the follicular fluid effects on progesterone secretion by cultures of immature granulosa cells and extends the effects of follicular fluid on luteinization processes to include modulation of $\mathrm{LH} / \mathrm{hCG}$ receptor induction in vitro by FSH + IFT. Addition of $50 \%$ follicular fluid obtained from large follicles enhanced progesterone secretion above that of cultures containing FSH + IFT alone. This stimulation of progesterone secretion in vitro is in sharp contrast to the inhibitory effect of fluid from small follicles observed with only $12.5 \%$ fluid added to the cultures. Follicular fluid also drastically altered the induction of $\mathrm{LH} / \mathrm{hCG}$ receptors in cultured granulosa cells. Although fluid from large follicles inhibited the $\mathrm{LH} / \mathrm{hCG}$ receptor induction of FSH + IFT, the inhibitory effect obtained with fluid from small follicles was significantly greater in all cultures at each concentration of fluid investigated. Follicular fluid exerted approximately the same effects upon FSH induction of hCG/LH binding sites and progesterone secretion whether or not it was charcoal treated, demonstrating that the effects of the fluid were not due solely to its steroid content or to other components removed by charcoal. These results indicate that the follicular fluid environment of maturing granulosa cells may be an important factor in the control of granulosa cell maturation and eventual luteinization. Whether or not the same factors within follicular fluid are responsible for both inhibition of progesterone secretion and inhibition of $\mathrm{LH} / \mathrm{hCG}$ receptor induction is not known. Neither is it known whether the stimulatory activity of fluid from large follicles on progesterone secretion by cultures of immature granulosa cells reported here and by others (Ledwitz-Rigby \& Rigby, 1979; Ledwitz-Rigby et al., 1981) is involved in regulation of LH/hCG receptor induction by FSH. Since Ledwitz-Rigby \& Rigbve(1979) observed a more than additive: 
stimulatory effect of follicular fluid from large follicles upon LH and FSH-mediated granulosa secretion of progesterone, it is unlikely that the stimulator is merely FSH or LH in the fluid. The values of $\mathrm{LH}$ and FSH measured in pig follicular fluid by radioreceptor assay were too low to account for the present effects (Kolena \& Channing, 1985).

The bulk of inhibitory activity upon FSH induction of hCG/LH binding sites exerted by fluid recovered from small and medium follicles appears to reside in the fraction of molecular weight decrease as the follicle develops from small to large. The relatively smaller amount of inhibitory activity upon $\mathrm{FSH}$ induction of $\mathrm{hCG} / \mathrm{LH}$ binding sites present in the filtrate, which is fairly constant as a function of follicular maturation, could represent some other component of the fluid or a low molecular weight component which binds to a high molecular weight complex or be a breakdown product of the substance found in retentate. If this were the case, high molecular weight material could be retained in the follicle more readily to maintain an inhibitory action on the small follicle to prevent it from luteinizing. The FSH-binding inhibitor isolated from cow follicular fluid by Darga \& Reichert (1978), Fletcher, Dias, Sanzo \& Reichert (1982) and Sluss, Fletcher \& Reichert (1983) and from human follicular fluid by Daume, Chari, Hopkinson \& Sturm (1979) is of low molecular weight and probably not the same as the "luteinization inhibitor" detected in follicular fluid from small pig follicles. FSH binding inhibitor is a low molecular weight inhibitor $\left(M_{\mathrm{r}} 1000\right)$ of FSH binding to granulosa or testis cells (Sluss et al., 1983). In the present studies we strived to avoid grossly atretic follicles, i.e. those visibly cloudy, and based on oocytes recovered from a pool of small follicles about $60-70 \%$ of the oocytes had compact cumuli of healthy appearance. The FSH binding inhibitor is present in higher concentration in atretic than in nonatretic follicles. In addition, fluid from atretic follicles of oestrous mares contains greater inhibitory activity on the secretion of progesterone than does fluid from non-atretic follicles (Channing, Batta, Condon, Ganjam \& Kenney, 1981).

The inhibitory activity upon FSH induction of hCG/LH binding sites was precipitated primarily with $70 \%$ ethanol which served to increase the ability of the inhibitor to act compared to the ability of the raw follicular fluid used as starting material. This $70 \%$ ethanol precipitate would therefore serve as a useful starting material for purification of the putative luteinization inhibitor.

We thank Ms Pat Gagliano, Mr Timothy Conn and Mr Joaquin Vallejo for technical assistance, and Mrs Gail Matthews for typing; and Dr Gordon Niswender, Department of Physiology and Biophysics, Colorado State University, Fort Collins, Colorado 80523, for a generous supply of progesterone antiserum; and Dr Robert Canfield, Department of Medicine, Columbia University, New York, NY 10032, for a supply of highly purified hCG. Supported in part by NIH grant HD08834 (C.P.C.) and NIH Training Grant HD00435, with additional support from USDA Cooperative Agreement CA-58-32440-158 (L.E.R.).

\section{References}

Amsterdam, A., Riesel, R., Mintz, Y., Shemesh, M. \& Salomon, Y. (1979) Inhibition of gonadotropin sensitive adenylate cyclase by ovarian follicular fluid. Biochem. Biophys. Res. Commun. 87, 505-512.

Bernard, J. (1973) Effet du liquide folliculaire sur la luteinization in vitro des cellules granulosaires du rat. C. r. Séanc. Soc. Biol. 167, 882-885

Bernard, J. (1975) Effect of follicular fluid and oestradiol on the luteinization of rat granulosa cells in vitro. $J$. Reprod. Fert. 43, 453-460.

Brunk, C.F., Jones, K.C. \& James, T.W. (1979) Assay for nanogram quantities of DNA in cellular homogenates. Analyst. Biochem. 92, 497-500.

Channing, C.P. (1970) Effect of stage of the estrous cycle and gonadotropins upon luteinization of porcine granulosa cells in culture. Endocrinology 87, 156-164.
Channing, C.P. (1980) Progesterone and estrogen secretion by cultured monkey ovarian cell types: influences of follicular size, serum luteinizing hormone levels, and follicular fluid estrogen levels. Endocrinology 107, 342-352.

Channing, C.P. \& Coudert, S.P. (1976) Contribution of granulosa cells and follicular fluid to ovarian estrogen secretion in the rhesus monkey in vivo. Endocrinology 98, 590-597.

Channing, C.P. \& Kammerman, S. (1973) Characteristics of gonadotropin receptors of porcine granulosa cells during follicle maturation. Endocrinology 92, 531546.

Channing, C.P. \& Ledwitz-Rigby, F. (1975) Methods for assessing hormone-mediated differentiation of ovarian cells in culture and in short term differentiation of Downloaded from Bioscientifica.com at 04/26/2023 10:08:49AM via free access 
ovarian cells in culture and in short term incubation. In Methods in Enzymology, vol. 39, pp. 183-200. Eds J. G. Hardman \& B. W. O'Malley. Academic Press, New York.

Channing, C.P., Tsai, V. \& Sachs, D. (1976) Role of insulin, cortisol and thyroxine in luteinization of porcine granulosa cells grown in chemically defined media. Biol. Reprod. 15, 235-247.

Channing, C.P., Brinkley, H.J. \& Young, E.P. (1980) Relationship between serum luteinizing hormone levels and the ability of porcine granulosa cells to luteinize and respond to exogenous luteinizing hormone in culture. Endocrinology 106, 317-322.

Channing, C.P., Batta, S.K., Condon, W., Ganjam, V.K. \& Kenney, R.M. (1981) Levels of inhibin activity and an atretogenic factor(s) in follicular fluid harvested from viable and atretic mare follicles. In Dynamics of Ovarian Function, pp. 73-78. Eds N. B. Schwartz \& M. Hunzicker-Dunn. Raven Press, New York.

Channing, C.P., Anderson, L.D., Hoover, D.J., Kolena, J., Osteen, K.G., Pomerantz, S.H. \& Tanabe, K. (1982) The role of non-steroidal regulators in control of oocyte and follicular maturation. Recent Prog. Horm. Res. 38, 331-408.

Darga, N.C. \& Reichert, L.E. (1978) Evidence for the presence of a low molecular weight follitropin binding inhibitor in bovine follicular fluid. Biol. Reprod. 19, 235-241.

Daume, E., Chari, S., Hopkinson, C.R.N. \& Sturm, G. (1979) Inhibition of follicle stimulating hormone binding to granulosa cells in vitro by human folicular fluid. Arch. Gynaek. 227, 289-292.

DiZerega, G.S., Goebelsmann, U. \& Nakamura, R.M. (1982) Identification of protein(s) secreted by the preovulatory ovary which suppresses the follicle response to gonadotropins. J. clin. Endocr. Metab. 54, 1091-1096.

Fletcher, D.W., Dias, J.A., Sanzo, M.A. \& Reichert, L.E., Jr (1982) Inhibition of FSH action on granulosa cells by low molecular weight components of follicular fluid. Molec. cell. Endocr. 25, 303-315.

Greenwood, F.C., Hunter, W.M. \& Glover, J.S. (1963) The preparation of ${ }^{125} \mathrm{I}$-human growth hormone of high specific radioactivity. Biochem. J. 89, 114123.

Hillensjö, T., Batta, S.K., Schwartz-Kripner, A., Wentz, A.C., Sulewski, J. \& Channing, C.P. (1978) Inhibitory effect of human follicular fuid upon the maturation of porcine oocytes in culture. J. clin. Endocr. Metab. 47, 1332-1335.

Kolena, J. \& Channing, C.P. (1985) Stimulatory action of follicular fluid components on maturation of granulosa cells from small porcine follicles. Horm. Res. (in press).

Kraiem, Z., Druker, B. \& Lunenfield, B. (1978) Inhibitory action of human follicular fluid on ovarian accumulation of cyclic AMP. J. Endocr. 78, 161-162.

Kumari, G.L., Vohra, S. \& Rayhavan, V. (1983) Effect of addition of human follicular fluid on progesterone secretion by cultured sheep granulosa cells. Endokrinologie 80, 135-141.

Ledwitz-Rigby, F. \& Rigby, B.W. (1979) Follicular fluid stimulation of steroidogenesis in immature granulosa cells in vitro. Molec. cell. Endocr. 14, 73-79.
Ledwitz-Rigby, F. \& Rigby, B.W., Gay, V.L., Stetson, M., Young, J. \& Channing, C.P. (1977) Inhibitory action of porcine follicular fluid upon granulosa cell luteinization in vitro: assay and influence of follicular maturation. J. Endocr. 74, 175-184.

Ledwitz-Rigby, F., Rigby, B.W., Long, S.Y., Stewart, L. \& McLean, M. (1981) Stimulation of granulosa cell maturation by follicular fluid. In Intraovarian Control Mechanisms, pp. 331-340. Eds C. P. Channing \& S. Segal. Plenum Press, New York.

Lindsey, A. \& Channing, C.P. (1979) Influence of follicular maturation upon the effect of ovine follicle stimulating hormone and luteinizing hormone upon cyclic AMP accumulation by isolated porcine granulosa cells. Biol. Reprod. 20, 473-482.

May, J.V. \& Schomberg, D.W. (1981) Granulosa cell differentiation in vitro: Effect of insulin on growth and functional integrity. Biol. Reprod. 25, 421431 .

May, J.V. \& Schomberg, D.W. (1984) Developmental coordination of $\mathrm{LH} / \mathrm{hCG}$ receptors and acute hCG responsiveness in cultured and freshly harvested porcine granulosa cells. Endocrinology 114, 153-163.

May, J.V., McCarty, K. Jr., Reichert, L.E. Jr. \& Schomberg, D.W. (1980) Follicle-stimulating hormone-mediated induction of functional luteinizing/ hormone human chorionic gonadotropin receptors during monolayer culture of porcine granulosa cells. Endocrinology 107, 1041-1049.

Nakano, R., Akahori, T., Katayama, K. \& Tojo, S. (1977) Binding of $\mathrm{LH}$ and FSH to porcine granulosa cells during follicular maturation. J. Reprod. Fert. 51, 2327.

Reichert, L. (1967) Selective inactivation of the luteinizing hormone contaminant in human pituitary follicle stimulating hormone preparations by digestion by $\alpha$ chymotrypsin. J. clin. Endocr. Metab. 27, 1065-1069.

Ryan, R. (1981) Follicular atresia : some speculations of biochemical markers and mechanisms. In Dynamics of Ovarian Function, pp. 1-11. Eds N. B. Schwartz \& M. Hunzicker-Dunn. Raven Press, New York.

Sakai, C., Channing, C.P. \& Engel, B. (1977) A bility of an extract of pig corpus luteum to inhibit binding of ${ }^{125}$ I-labeled human chorionic gonadotropin to porcine granulosa cells. Proc. Soc. exp. Biol. Med. 155, 373-376.

Shemesh, M. (1979) Inhibitory action of follicular fluid on progesterone and prostaglandin synthesis in bovine follicles. J. Endocr. 82, 27-31.

Sluss, P.M. \& Reichert, L.E. Jr. (1983) Presence of bacteria in porcine follicular fluid and their ability to generate an inhibitor of follicle-stimulating hormone binding to receptor. Biol. Reprod. 29, 335-341.

Sluss, P.M., Fletcher, P.W. \& Reichert, L.E., Jr (1983) Inhibition of ${ }^{125}$ I-human follicle-stimulating hormone binding to receptor by a low molecular weight fraction of bovine follicular fluid: Inhibitor concentration is related to biochemical parameters of follicular development. Biol. Reprod. 29, 1105-1113.

Stone, S.L., Pomerantz, S.H., Kripner, A.S. \& Channing, C.P. (1978) Inhibitor of oocyte maturation from porcine follicular fluid: further purification and evidence for reversible action. Biol. Reprod. 19, 585592. 